\title{
Sensitive High Resolution Ion Microprobe (SHRIMP Ile/MC) of the Institute of Geosciences of the University of São Paulo, Brazil: analytical method and first results Microssonda Iônica de Alta Resolução e de Alta Sensibilidade (SHRIMP IIe/MC) do Instituto de Geociências da Universidade de São Paulo, Brasil: método analítico e primeiros resultados
}

\author{
Kei Sato ${ }^{1}$, Colombo Celso Gaeta Tassinari ${ }^{1}$, Miguel Angelo Stipp Basei ${ }^{1}$, Oswaldo Siga Júnior ${ }^{1}$, \\ Artur Takashi Onoe ${ }^{1}$, Maurício Dias de Souza ${ }^{1}$ \\ ${ }^{1}$ Instituto de Geociências, Universidade de São Paulo - USP, Rua do Lago 562, CEP 05508-080, São Paulo, SP, BR \\ (keisato@usp.br; ccgtassi@usp.br; baseimas@usp.br; osigajr@usp.br; aton@usp.br; mauriciods@usp.br)
}

Received on $7^{\text {th }}$ August 2013; accepted on $5^{\text {th }}$ May 2014

\begin{abstract}
This paper presents the characteristics of the high resolution secondary ion mass spectrometer coupled with an Ion Microprobe (SHRIMP IIe/MC), installed at the Institute of Geosciences of the University of São Paulo (IGc-USP), as well as the respective analytical procedures and the first results obtained with standard samples, making possible to conduct routine analysis of zircon samples. The standard of the Temora 2 zircon, with age of $416.78 \mathrm{Ma}$, was analyzed by the SHRIMP IIe/ MC at the Institute of Geosciences of the University of São Paulo and yielded the age of $416.8 \pm 3.8 \mathrm{Ma}$. Samples of the Archean zircon OG1 and the Neoproterozoic zircon Z6266, which yielded U-Pb ages of 3465.4 $\pm 0.6 \mathrm{Ma}$ and of $559 \pm 0.2 \mathrm{Ma}$, respectively, using Thermal Ionization Mass Spectrometry (TIMS), were analyzed by SHRIMP IIe/MC at the IG-USP and yielded U-Pb ages of 3462.6 $\pm 5.1 \mathrm{Ma}$ and $561.0 \pm 0.92 \mathrm{Ma}$, respectively, in Concordia diagrams. Therefore, these values and the literature values are very close. Both OG1 and Z6266 samples, due to the homogeneity in their composition and isotopic relationship, can be used as SHRIMP standard. These results indicate that data obtained using SHRIMP IIe at the IGc-USP are reliable and compatible with international standards. Dating of samples with ages ranging from Cenozoic to Archean, obtained using SHRIMP IIe/MC U-Pb geochronology on zircon crystals, is presented here to illustrate this point.
\end{abstract}

Keywords: U-Pb zircon ages; SHRIMP; Geochronology; IGc-USP; Temora standard.

\section{Resumo}

Este trabalho apresenta as características de espectrômetro de massa de íons secundários acoplado com uma Microssonda Iônica de Alta Resolução, do tipo SHRIMP IIe/MC, instalada no Instituto de Geociências da Universidade de São Paulo (IGc-USP), bem como os respectivos procedimentos analíticos e os primeiros resultados obtidos em amostra de padrões, tornando-a apta a operar para análises em rotina de amostras de zircão. O padrão de zircão Temora 2, com idade de 416,78 Ma, foi analisado no SHRIMP IIe/MC de IGc-USP e apresentou a idade de 416,8 \pm 3,8 Ma. As amostras de zircão arqueano OG1 e de zircão neoproterozoico Z6266, respectivamente com idades U-Pb obtidas por Espectrometria de Massa de Ionização Térmica (TIMS) de 3465,4 \pm 0,6 Ma e de $559 \pm$ 0,2 Ma foram analisadas no SHRIMP IIe de IG-USP e apresentaram idades U-Pb em diagramas Concórdia de 3462,6 \pm 5,1 Ma e 561,0 \pm 0,92 Ma respectivamente, portanto muito próximos aos valores referenciados na literatura. Tanto a amostra OG1 como a Z6266, em razão da homogeneidade de suas composições e das relações isotópicas, poderão ser utilizadas como padrões para SHRIMP. Esses resultados indicam que o SHRIMP IIe/MC do IGc-USP produz dados confiáveis compatíveis com os padrões internacionais. Como exemplos são aqui apresentadas datações de amostras de idades variáveis, desde cenozoica até arqueana, efetuadas pelo método geocronológico U-Pb por meio de SHRIMP IIe em cristais de zircão.

Palavras-chave: Idade U-Pb em zircão; SHRIMP; Geocronologia; IGc-USP; Temora. 


\section{INTRODUCTION}

\section{History \\ Development of Sensitive \\ High Resolution Ion Microprobe}

The design of Sensitive High Resolution Ion Microprobe (SHRIMP) I was based on an ion optical description by Matsuda (1974) for a double-focusing high mass-resolution mass spectrometer (Clement et al., 1977). The magnet was made as large as manufacturing capabilities allowed with a turning radius of $1.000 \mathrm{~m}$, thus yielding a secondaryion beam path of $7 \mathrm{~m}$. The other components in the mass analyzer were an electrostatic analyzer, radius $1.272 \mathrm{~m}$, used to correct the large velocity spread characteristic of (Secondary Ion Mass Spectrometer (SIMS), and an electrostatic quadrupole lens located between the Electrostatic Analyzer (ESA) and magnet, used by Matsuda to reduce second-order aberrations (additional information you can see by Ireland et al., 2008; Compston et al., 1984; Williams, 1998).
The SHRIMP IIe was installed at the Laboratory of High Resolution Geochronology of the Institute of Geosciences of the University of São Paulo (GeoLab-IGc-USP) in October, 2010 by staffs (professor, engineers and technicians) of the Australian Scientific Instruments (Figure 1). The mass spectrometer model is SHRIMP IIe/MC, in which "II" mean second generation and "e" mean extended, and MC is because it has a multicollector detector system with five multi-ion counting (MIC - continuous dynode), one electron multiplier (ETP - discrete dynode) and one Faraday cup. In this machine, it is possible to measure both positive and negative isotopes. Since 2011, the GeoLab-IGc-USP has obtained very accurate zircon $\mathrm{U}-\mathrm{Pb}$ isotopic data, and there are plans, in the near future, for dating other minerals, as baddeleyite, titanite, xenotime and monazite, and also for analyzing stable isotopes, such as oxygen in zircon. The main purpose of this paper is to present analytical procedures for the U-Pb analysis of zircons using SHRIMP IIe, the first isotopic results obtained on international zircon standard/samples: Temora 2 (Paleozoic - Black et al., 2004), OG1 (Archean - Stern et al., 2009) and Z6266 (Neoproterozoic - Stern and Amelin, 2003), as well as some examples from South American Platform.

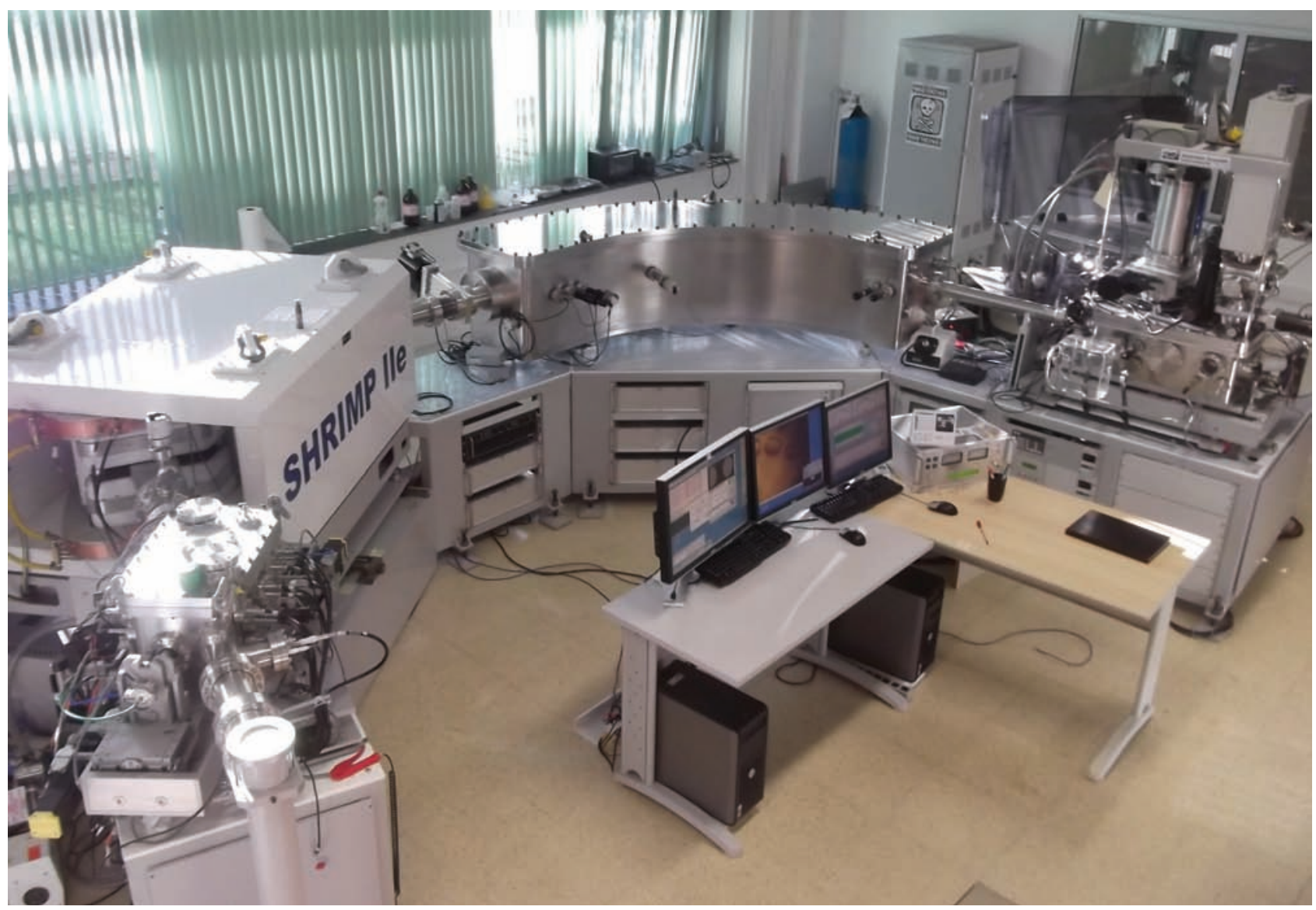

Figure 1. Picture of the SHRIMP Ile/MC at Institute of Geosciences of the University of São Paulo. 


\section{ANALYTICAL PROCEDURES FOR U-Pb ISOTOPIC ANALYSIS USING SHRIMP IIE/MC AT GeoLab-IGc-USP}

\section{Mount preparation and imagery}

Zircons from each sample were arranged in rows with Temora 2 zircon reference standard, cast into epoxy resin grain mounts with a diameter of $2.54 \mathrm{~cm}$, and polished with diamond compound $(1-7 \mu \mathrm{m})$ to reveal grain centers. Methodology for sample preparation and hand picking can be seen in the Appendix 1 .

Cleaning procedures:

(1) wash with detergent;

(2) wash for five minutes with diluted $\mathrm{HNO}_{3}(1 \%)$;

(3) wash three times with Petroleum Spirit;

(4) wash three times with ultrapure hot water (MILIQ 50-60 ${ }^{\circ} \mathrm{C}$ );

(5) dry at $50-60^{\circ} \mathrm{C}$ for 2 hours in a clean room.

Note: washing procedure described from step 1 to 4 was carried out in ultrasonic bath.

Optical and electronic imagery:

(1) reflected and transmitted light images were acquired before gold coating of $2-3 \mu \mathrm{m}$;

(2) cathodoluminescence (CL) images were obtained by FEI Quanta 250 Scanning Electron Microscope (SEM) and XMAX CL detector (Oxford Instruments). SEM analytical conditions are: high voltage $=15 \mathrm{kV}$, work distance $=16.9 \mathrm{~mm}$, detector $=$ PMD, filament emission $=100 \mu \mathrm{A}$, and magnification range $=95$ to $250 \mathrm{x}$;

(3) after CL acquisition, the gold was removed and the mount was recleaned;

(4) the thickness $(\sim 3 \mu \mathrm{m})$ of the final gold coating was reached after a two-minutes exposition and an electrical conductivity resistance of approximately $15-17 \Omega$ (between the border and the center of mount). Then, it was ready to be analyzed by the SHRIMP IIe.

\section{SHRIMP Ile analytical setup}

The SHRIMPIIe setup at the GeoLab-IGc-USP is described below:

(i) Primary beam analytical conditions: Kohler aperture = $120 \mu \mathrm{m}$, spot size $=30 \mu \mathrm{m}$, and $\mathrm{O}_{2}^{-}$, beam density $=$around $2.5-7 \eta \mathrm{A}$ (dependent of brightness aperture).

(ii) Secondary beam analytical conditions: source slit $=80 \mu \mathrm{m}$; mass resolutions for ${ }^{196}\left(\mathrm{Zr}_{2} \mathrm{O}\right),{ }^{206} \mathrm{~Pb},{ }^{207} \mathrm{~Pb},{ }^{208} \mathrm{~Pb},{ }^{238} \mathrm{U},{ }^{248}(\mathrm{ThO})$ and ${ }^{254}$ (UO) ranging between 5,000 and 5,500 (1\%), and residues $<0.025$ (Appendix 2); energy slit = open.

\section{Acquisition table setup}

Raster time is $2-3$ minutes with spot size $=50 \mu \mathrm{m}$, plus 0.5 minutes of burning time fixed at the center. Acquisition parameters are shown in Table 1.

\section{Setup conditions of the acquisition table}

Primary beam autotune is systematically carried out in the Source Steering Y and Source Steering Z focus lens (Appendix 3), and secondary beam autotune QT1Y and QT1Z are enabled (Appendix 4). Auto run selector is ${ }^{254}$ (UO), in which auto center method is measured at $50 \%$ of the peak height. The analytical cycle number is equal to 5 cycles for Neoproterozoic-Archean samples, and equal to 6 - 7 cycles for Phanerozoic samples. All raw count rates have been corrected for a dead time of 25 ns and analytical rate among standard and sample is 1 standard to 4 zircon samples.

\section{Acquisition and data processing}

$\mathrm{U}-\mathrm{Pb}$ calibration: the $\mathrm{Pb}^{+}$ionization efficiency is about a factor of two higher than $\mathrm{U}^{+}$, and so the ${ }^{206} \mathrm{~Pb}^{+} / 238 \mathrm{U}^{+}$ratio must be calibrated by a standard material (Williams, 1998). Measured ${ }^{206} \mathrm{~Pb}^{+} / 238 \mathrm{U}^{+}$varies with the measured $\mathrm{UO}^{+} / \mathrm{U}^{+}$to define a calibration line of known age, in this case 416,78 Ma for Temora 2 (Figure 2) or $572 \mathrm{Ma}$ for SL13. Figure 2 shows $\operatorname{Ln}(\mathrm{Pb} / \mathrm{U}) \times \mathrm{Ln}(\mathrm{UO} / \mathrm{U})$ trend line with slope of 2.14 . The age of an unknown sample can then be determined by the ratio of ${ }^{206} \mathrm{~Pb}^{+} / \mathrm{U}^{+}$in the unknown to that ratio in the standard at the common $\mathrm{UO} / \mathrm{U}$ value. For additional information, please see Williams (1998).

SHRIMP softwares are LabVIEW 8.5 and SHRIMP SW, version 2.1. Data was reduced using SQUID 1.06, and the Concordia Diagram was plotted using ISOPLOT 4 (Ludwig, 2009). Common lead corrections usually use ${ }^{204} \mathrm{~Pb}$ according to Stacey and Kramer (1975), but the software SQUID has the option to use ${ }^{207} \mathrm{~Pb}$ and ${ }^{208} \mathrm{~Pb}$ corrections. Temora 2 is used as ${ }^{206} \mathrm{~Pb} /{ }^{238} \mathrm{U}$ age reference (416.78 Ma, Black et al., 2004), and SL13 (238 ppm) is used as U composition reference. Analytical uncertainties are shown in Tables 2 and 3 in $1-\Sigma$ error for each analysis.

\section{ANALYSIS BY SHRIMP IIE OF TEMORA 2 STANDARD AND Z6266 AND OG1 SAMPLES AT GeoLab-IGc-USP}

The Temora 1 zircon, as well as the Temora 2 zircon, is crystallized within the Middledale Gabbroic Diorite (Black et al., 2004). This body forms a small, high-level stock within the Paleozoic Lachlan Orogen of Eastern Australia. The weighted mean U-Pb age (416.78 $\pm 0.33 \mathrm{Ma}$ ) measured by ID-TIMS (Isotope Dilution - Thermal Ionization Mass Spectrometry) and obtained from the nine Temora 2 analyses is interpreted as the best estimated age for these zircon crystals (Black et al., 2004).

The Z6266 zircon comprises clear, colorless, glassy megacryst fragments from Sri Lanka (Stern, 2001). Evidence for 

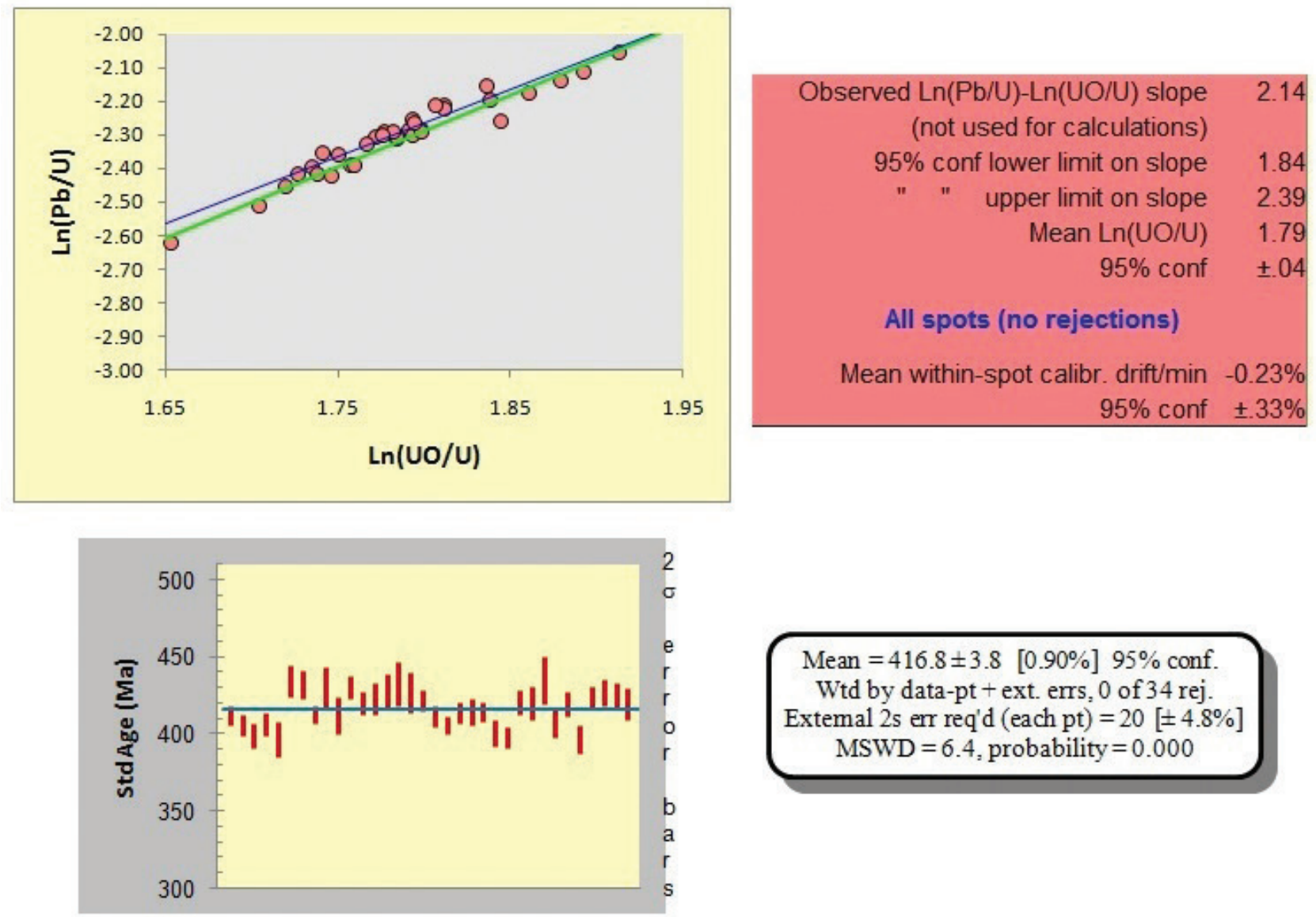

Mean $=416.8 \pm 3.8[0.90 \%] 95 \%$ conf.

Wtd by data-pt + ext. errs, 0 of 34 rej.

Extemal 2 s err req'd (each pt) $=20[ \pm 4.8 \%]$

MSWD $=6.4$, probability $=0.000$

The weighted mean age for 34 analyses is $416.8 \pm 3.8 \mathrm{Ma}$. For 3 days, the age varied within an error of $0.9 \%$ and $\operatorname{Ln}(\mathrm{Pb} / \mathrm{U}) \times \mathrm{Ln}(\mathrm{UO} / \mathrm{U})$ slope $=2.14$. (For data, see Table 2.)

Figure 2. (Top) $\mathrm{Ln}(\mathrm{Pb} / \mathrm{U})$ versus $\mathrm{Ln}(\mathrm{UO} / \mathrm{U})$ calibration diagram for Temora 2 standard analyzed for 3 consecutive days (72 hours); (bottom) bar graph of ${ }^{206} \mathrm{~Pb} /{ }^{238} \mathrm{U}$ ages (Ma) for Temora 2 analyzed for 72 hours.

Table 1. Acquisition setup table.

\begin{tabular}{|c|c|c|c|c|c|c|c|c|c|}
\hline & $\mathrm{Zr}_{2} \mathrm{O}$ & ${ }^{204} \mathrm{~Pb}$ & 204.1 & ${ }^{206} \mathrm{~Pb}$ & ${ }^{207} \mathrm{~Pb}$ & ${ }^{208} \mathrm{~Pb}$ & ${ }^{238} \mathrm{U}$ & ${ }^{248} \mathrm{ThO}$ & ${ }^{254} \mathrm{UO}$ \\
\hline$D(s)$ & 5 & 3 & 1 & 2 & 1 & 1 & 2 & 2 & 2 \\
\hline IT (s) & 2 & 10 & 10 & $10^{*}$ & $20^{*}$ & 2 & 10 & 5 & 5 \\
\hline$A C$ & ON & OFF & OFF & $\mathrm{ON}^{*}$ & OFF & OFF & ON & ON & ON \\
\hline
\end{tabular}

D: delay; s: seconds; IT: analytical integration time; AC: mass auto center; ON: enabled; OFF: disabled; * integration time to low U concentration or young zircon, $<300 \mathrm{Ma}$, is changed to $20 \mathrm{~s}$ to ${ }^{206} \mathrm{~Pb}$ and $30-40 \mathrm{~s}$ to ${ }^{207} \mathrm{~Pb}$ and Auto Center is operated in OFF mode conditions.

$\mathrm{U} / \mathrm{Pb}$ homogeneity of these materials includes TIMS U-Pb analyses obtained in two different laboratories, and ages are consistent and within analytical error. The Z6266 zircon yielded an weighted ${ }^{206} \mathrm{~Pb} /{ }^{238} \mathrm{U}$ age of $559.0 \pm 0.2 \mathrm{Ma}$, and ID-TIMS analysis gave a mean U concentration of 903 $\pm 23 \mathrm{ppm}$, total $\mathrm{Pb}=79 \pm 2 \mathrm{ppm}$ and $\mathrm{Th}=199 \pm 6 \mathrm{ppm}$ (Stern and Amelin, 2003).

Sample OG1 is a quartz diorite body from Pilbara Craton, Western Australia (Stern et al., 2009). TIMS ${ }^{207} \mathrm{~Pb} /{ }^{206} \mathrm{~Pb}$ reference value for OG1 zircon was $0.29907 \pm 0.00011$, which is equivalent to an age of $3465.4 \pm 0.6 \mathrm{Ma}$. The OG1 zircons analyzed by SHRIMP RG at the Australian National University (ANU) yielded weighted mean ${ }^{207} \mathrm{~Pb} /{ }^{206} \mathrm{~Pb}$ age of $3468.1 \pm 1.2 \mathrm{Ma}$, whereas the robust mean ${ }^{206} \mathrm{~Pb} /{ }^{238} \mathrm{U}$ age was $3449 \pm 10$ Ma.

\section{Results at GeoLab-IGc-USP}

Cathodoluminescence images (CL) of Temora 2, Z6266 and OG1 zircon crystals are shown respectively in Appendix 5, 6 and 7, and the analytical results of U-Pb dating of these zircons using SHRIMP IIe at Geo-Lab-IGc-USP are shown in Tables 2 and 3. 
Table 2. $\mathrm{Ln}(\mathrm{UO} / \mathrm{U}) \times\left(\mathrm{Ln}(\mathrm{Pb} / \mathrm{U})\right.$ data and ${ }^{206} \mathrm{~Pb} / 238 \mathrm{U}$ reference age from Temora $2 . \mathrm{Ln}\left(\mathrm{UO}^{+} / \mathrm{U}^{+}\right)$correlate directly with $\mathrm{Ln}\left(\mathrm{Pb}^{+} / \mathrm{U}^{+}\right)$, so that it was possible to determine a correction factor.

\begin{tabular}{|c|c|c|c|c|c|c|c|c|c|c|c|c|c|c|c|c|c|}
\hline $\begin{array}{l}\text { Spot } \\
\text { name }\end{array}$ & $\underset{U}{\mathrm{ppm}}$ & $\begin{array}{l}\text { ppm } \\
\text { Th }\end{array}$ & $\begin{array}{c}{ }^{232} \mathrm{Th} / \\
{ }^{238} \mathrm{U}\end{array}$ & $\begin{array}{l}{ }^{204} \mathrm{~Pb} / \\
{ }^{206} \mathrm{~Pb}\end{array}$ & $\begin{array}{l}\% \\
\text { err }\end{array}$ & $\begin{array}{c}\% \\
\text { comm } \\
{ }_{206} \mathrm{~Pb}\end{array}$ & $\begin{array}{l}\text { Total } \\
{ }^{208} \mathrm{~Pb} / \\
{ }^{206} \mathrm{~Pb}\end{array}$ & $\begin{array}{l}\% \\
\text { err }\end{array}$ & $\begin{array}{l}\text { Total } \\
{ }^{238} \mathrm{U} / \\
{ }^{206} \mathrm{~Pb}\end{array}$ & $\begin{array}{l}\% \\
\text { err }\end{array}$ & $\begin{array}{l}\text { Total } \\
{ }^{207} \mathrm{~Pb} / \\
{ }^{206} \mathrm{~Pb}\end{array}$ & $\begin{array}{c}\% \\
\text { err }\end{array}$ & $\begin{array}{c}{ }^{204} \mathrm{~Pb} \\
{ }^{206 r} \mathrm{~Pb} / \\
{ }^{238} \mathrm{U} \\
\mathrm{Age}\end{array}$ & $\begin{array}{l}1 \sigma \\
\text { err }\end{array}$ & $\begin{array}{l}\mathrm{Ln} \\
\text { (UO/U) }\end{array}$ & $\begin{array}{c}\mathrm{Ln} \\
(\mathrm{Pb} / \mathrm{U})\end{array}$ & $\begin{array}{c}{ }^{204} \mathrm{~Pb} \\
\mathrm{~Pb} / \mathrm{U}^{\text {corr }} \\
\mathrm{UO} / \mathrm{U}^{\wedge} 2\end{array}$ \\
\hline TEM-1.1 & 566 & 189 & 0.34 & 0.00041 & 35 & 0.77 & 0.108 & 2.3 & 0.129 & 2.6 & 0.056 & 2.6 & 413 & 3 & 1.913 & -2.057 & 0.00279 \\
\hline TEM-1.2 & 447 & 251 & 0.58 & 0.00059 & 32 & 1.10 & 0.190 & 2.0 & 0.119 & 2.8 & 0.063 & 2.4 & 406 & 4 & 1.879 & -2.141 & 0.00275 \\
\hline TEM-1.3 & 347 & 185 & 0.55 & 0.00052 & 41 & 0.96 & 0.171 & 2.5 & 0.114 & 2.3 & 0.058 & 2.9 & 399 & 4 & 1.861 & -2.177 & 0.00270 \\
\hline TEM-2.1 & 368 & 134 & 0.38 & -0.00014 & 2 & -0.27 & 0.123 & 3.0 & 0.121 & 2.6 & 0.063 & 3.8 & 407 & 4 & 1.893 & -2.112 & 0.00275 \\
\hline TEM-2.2 & 185 & 65 & 0.36 & 0.00086 & 34 & 1.61 & 0.138 & 3.6 & 0.106 & 2.8 & 0.066 & 4.3 & 397 & 6 & 1.844 & -2.259 & 0.00269 \\
\hline TEM-3.1 & 221 & 111 & 0.52 & 0.00047 & 44 & 0.88 & 0.171 & 4.3 & 0.117 & 2.0 & 0.066 & 3.4 & 435 & 5 & 1.836 & -2.154 & 0.00295 \\
\hline TEM-3.3 & 345 & 166 & 0.50 & 0.00013 & 136 & 0.24 & 0.171 & 2.8 & 0.101 & 2.3 & 0.061 & 3.9 & 432 & 4 & 1.777 & -2.290 & 0.00293 \\
\hline TEM-3.4 & 930 & 281 & 0.31 & 0.00027 & 13 & 0.50 & 0.097 & 2.1 & 0.102 & 1.9 & 0.058 & 1.9 & 413 & 3 & 1.791 & -2.286 & 0.00280 \\
\hline TEM-4.2 & 160 & 44 & 0.28 & 0.00084 & 41 & 1.57 & 0.125 & 4.3 & 0.107 & 2.0 & 0.074 & 4.5 & 431 & 7 & 1.793 & -2.252 & 0.00292 \\
\hline TEM-4.3 & 258 & 125 & 0.50 & 0.00094 & 35 & 1.75 & 0.168 & 4.5 & 0.091 & 1.3 & 0.063 & 4.8 & 412 & 6 & 1.726 & -2.417 & 0.00279 \\
\hline TEM-5.1 & 472 & 148 & 0.32 & 0.00035 & 65 & 0.66 & 0.106 & 2.6 & 0.110 & 2.7 & 0.060 & 2.4 & 431 & 4 & 1.812 & -2.211 & 0.00292 \\
\hline TEM-5.2 & 467 & 163 & 0.36 & 0.00065 & 28 & 1.22 & 0.121 & 2.6 & 0.096 & 1.9 & 0.060 & 2.6 & 420 & 4 & 1.751 & -2.358 & 0.00285 \\
\hline TEM-5.3 & 372 & 206 & 0.57 & 0.00088 & 35 & 1.65 & 0.186 & 2.6 & 0.101 & 2.2 & 0.063 & 3.8 & 423 & 5 & 1.784 & -2.312 & 0.00287 \\
\hline TEM-6.1 & 797 & 287 & 0.37 & 0.00018 & 54 & 0.33 & 0.117 & 3.4 & 0.109 & 0.8 & 0.057 & 2.0 & 428 & 6 & 1.812 & -2.223 & 0.00290 \\
\hline TEM-7.1 & 136 & 66 & 0.51 & 0.00047 & 66 & 0.87 & 0.180 & 8.1 & 0.111 & 2.3 & 0.069 & 7.7 & 433 & 7 & 1.807 & -2.211 & 0.00294 \\
\hline TEM-7.2 & 200 & 91 & 0.47 & 0.00093 & 41 & 1.75 & 0.173 & 3.4 & 0.101 & 3.1 & 0.068 & 3.8 & 427 & 7 & 1.784 & -2.307 & 0.00289 \\
\hline TEM-8.1 & 605 & 379 & 0.65 & 0.00030 & 30 & 0.57 & 0.200 & 1.9 & 0.102 & 2.0 & 0.057 & 2.4 & 422 & 3 & 1.782 & -2.293 & 0.00286 \\
\hline TEM-8.2 & 581 & 165 & 0.29 & 0.00019 & 22 & 0.36 & 0.098 & 2.7 & 0.101 & 1.9 & 0.059 & 2.6 & 412 & 3 & 1.793 & -2.299 & 0.00279 \\
\hline TEM-8.3 & 800 & 310 & 0.40 & 0.00021 & 43 & 0.38 & 0.125 & 2.7 & 0.092 & 2.7 & 0.059 & 2.1 & 406 & 3 & 1.757 & -2.388 & 0.00275 \\
\hline TEM-8.4 & 790 & 276 & 0.36 & 0.00043 & 35 & 0.80 & 0.117 & 2.3 & 0.087 & 2.5 & 0.059 & 2.3 & 414 & 4 & 1.719 & -2.455 & 0.00280 \\
\hline TEM-9.1 & 315 & 210 & 0.69 & 0.00082 & 33 & 1.54 & 0.212 & 3.4 & 0.113 & 1.4 & 0.061 & 3.0 & 415 & 4 & 1.838 & -2.199 & 0.00281 \\
\hline TEM-9.2 & 582 & 138 & 0.24 & 0.00047 & 33 & 0.87 & 0.082 & 2.7 & 0.103 & 1.8 & 0.059 & 3.1 & 414 & 3 & 1.798 & -2.285 & 0.00280 \\
\hline TEM-9.4 & 440 & 203 & 0.48 & 0.00019 & 88 & 0.35 & 0.150 & 2.4 & 0.089 & 2.7 & 0.062 & 2.7 & 401 & 4 & 1.746 & -2.421 & 0.00271 \\
\hline TEM-9.5 & 276 & 151 & 0.56 & 0.00042 & 17 & 0.78 & 0.170 & 2.7 & 0.082 & 2.3 & 0.058 & 2.3 & 398 & 4 & 1.704 & -2.512 & 0.00269 \\
\hline TEM-10.1 & 287 & 141 & 0.51 & 0.00099 & 28 & 1.85 & 0.172 & 2.7 & 0.103 & 1.8 & 0.063 & 3.7 & 421 & 4 & 1.798 & -2.291 & 0.00285 \\
\hline TEM-10.2 & 306 & 155 & 0.52 & 0.00029 & 59 & 0.54 & 0.170 & 2.4 & 0.092 & 2.8 & 0.059 & 3.8 & 420 & 6 & 1.735 & -2.396 & 0.00285 \\
\hline TEM-11.1 & 292 & 141 & 0.50 & 0.00046 & 43 & 0.86 & 0.166 & 2.7 & 0.096 & 2.3 & 0.065 & 3.0 & 435 & 8 & 1.742 & -2.355 & 0.00295 \\
\hline TEM-11.2 & 285 & 138 & 0.50 & 0.00087 & 25 & 1.62 & 0.152 & 3.2 & 0.093 & 2.2 & 0.064 & 3.4 & 407 & 5 & 1.759 & -2.390 & 0.00276 \\
\hline TEM-11.3 & 456 & 226 & 0.51 & 0.00039 & 33 & 0.73 & 0.161 & 2.8 & 0.090 & 1.3 & 0.061 & 2.8 & 419 & 4 & 1.738 & -2.415 & 0.00284 \\
\hline TEM-11.4 & 421 & 210 & 0.52 & 0.00071 & 33 & 1.34 & 0.172 & 2.7 & 0.074 & 2.1 & 0.060 & 5.3 & 397 & 5 & 1.653 & -2.623 & 0.00268 \\
\hline TEM-12.1 & 529 & 280 & 0.55 & 0.00042 & 26 & 0.79 & 0.169 & 2.1 & 0.105 & 1.3 & 0.061 & 2.4 & 424 & 4 & 1.794 & -2.265 & 0.00287 \\
\hline TEM-12.2 & 384 & 211 & 0.57 & 0.00055 & 41 & 1.03 & 0.177 & 2.4 & 0.101 & 2.4 & 0.061 & 3.0 & 427 & 4 & 1.772 & -2.308 & 0.00290 \\
\hline TEM-13.1 & 355 & 180 & 0.53 & 0.00052 & 32 & 0.98 & 0.172 & 3.9 & 0.101 & 1.6 & 0.062 & 3.7 & 425 & 4 & 1.775 & -2.299 & 0.00288 \\
\hline TEM-14.1 & 404 & 196 & 0.50 & 0.00050 & 35 & 0.93 & 0.171 & 2.2 & 0.098 & 1.5 & 0.060 & 2.6 & 419 & 5 & 1.767 & -2.327 & 0.00284 \\
\hline Wtd mean & & & & & & & & & & & & & 416.8 & & & & 0.00282 \\
\hline $2 \sigma$ error & & & & & & & & & & & & & $0.90 \%$ & & & & $0.97 \%$ \\
\hline
\end{tabular}

err: error; comm: common; corr: corrected; Wtd: weighted. Jamal et al., unpublished data.

\section{Temora 2 zircon standard}

Figure 2 (top left and right) shows the $\mathrm{Ln}(\mathrm{Pb} / \mathrm{U})$ versus $\mathrm{LN}(\mathrm{UO} / \mathrm{U}$ ) diagram of the Temora Standard analyzed for 3 days (34 spots, Table 2). There is a good correlation among the analytical points shown in this diagram. Figure 2 (bottom) presents a ${ }^{206} \mathrm{~Pb} /{ }^{238} \mathrm{U}$ ages bar graph diagram indicating a weighted average value of $416.8 \pm 3.8 \mathrm{Ma}$. This number is very close to that obtained by Black et al. (2004), with low error dispersion ranging from 0.9 to $95 \%$ confidence. For SHRIMP stability and calibration tests and Temora zircon homogeneity test, we analyzed 26 Temora zircon (8 standard and 18 normal sample). Figure 3A shows a 


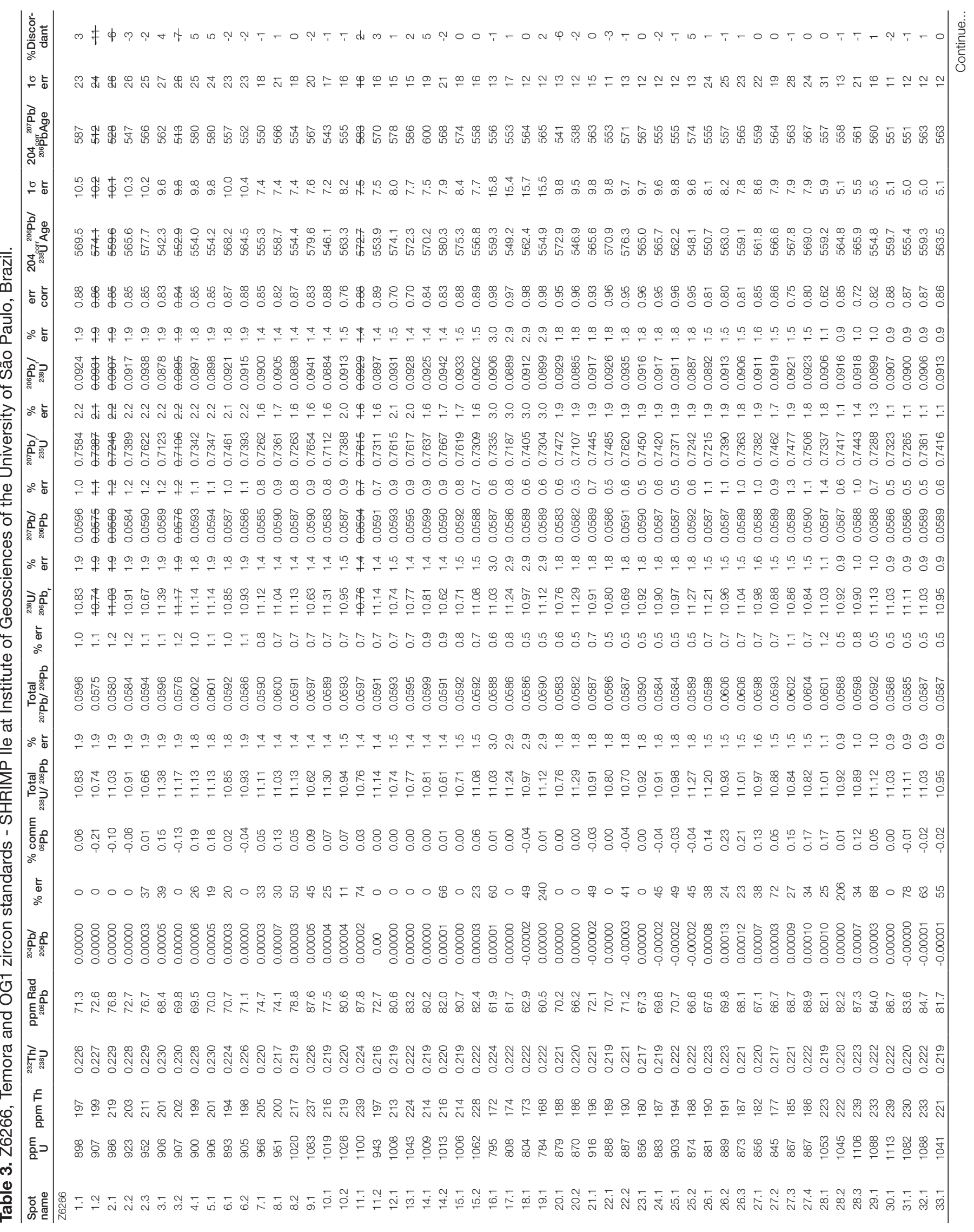




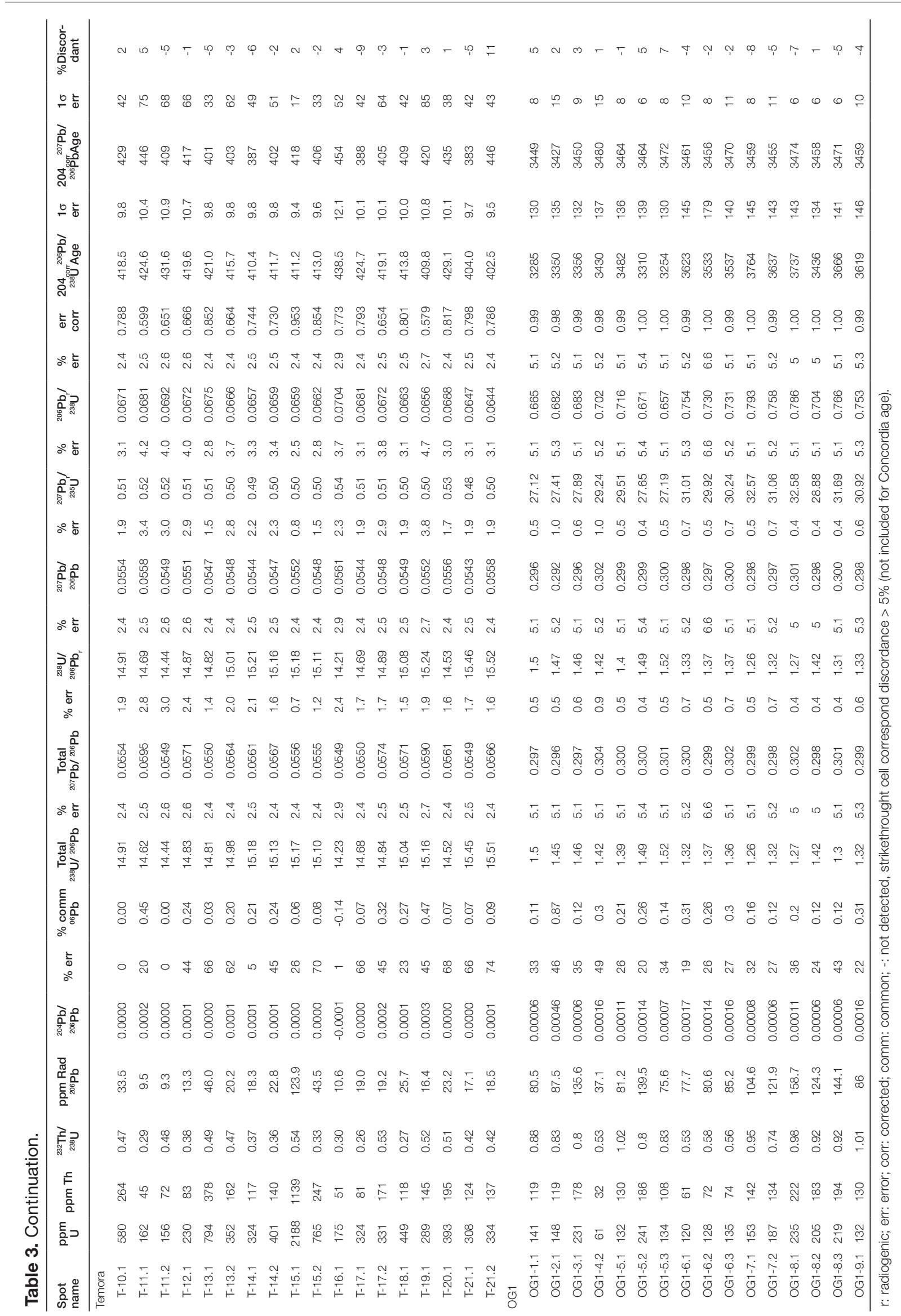


Concordia diagram with age of $416.7 \pm 2.3 \mathrm{Ma}$ and Figures 3B and $3 \mathrm{C}$ shows Concordia diagram with U (ppm, color scale) and Concordia diagram with common $\mathrm{Pb}$ (color scale). Figure 3D shows a histogram (left) and the respective bar graph (right) of ${ }^{206} \mathrm{~Pb} /{ }^{238} \mathrm{U}$ age of Temora 2 analyzed it as an unknown sample. The analytical location points can be seen at CL image (Appendix 5) and the analytical data is in the Table 3 . The Concordia age of $416.7 \pm 2.3$ Ma with low mean square weighted deviation $(\mathrm{MSWD})=0.103$ and the ${ }^{206} \mathrm{~Pb} /{ }^{238} \mathrm{U}$ weighted average age of $417.0 \pm 4.7 \mathrm{Ma}$ with an equivalent error of $1.1 \%$ are very close to the true value. The precision and error are dependents of $\mathrm{U}$ concentration and common $\mathrm{Pb}$ content (Figures $3 \mathrm{~B}$ and $3 \mathrm{C}$ ). The histogram (Figure 3D) shows a unimodal Gaussian distribution. The difference of ${ }^{206} \mathrm{~Pb} /{ }^{238} \mathrm{U}$ ages among Figure 2 (bar graph) and Figure $3 \mathrm{D}$ is in the analytical period. Figure 2 shows ${ }^{206} \mathrm{~Pb} /{ }^{28} \mathrm{U}$ ages obtained during 3 consecutive days, demonstrating a good stability for long period (416.8 $\pm 3.8 \mathrm{Ma}-$ Figure 2$)$ with an equivalent error of $0.9 \%$, while the ${ }^{206} \mathrm{~Pb} /{ }^{238} \mathrm{U}$ average age to half day is $417.0 \pm 4.7 \mathrm{Ma}$ (Figure 3D) with an error of $1.1 \%$. For small number of data ( $10-15$ analysis), the error expected for ${ }^{206} \mathrm{~Pb} /{ }^{238} \mathrm{U}$ Temora age is $<1.5 \%$; therefore, our result can be considered of good quality.

\section{Z6266 zircon sample}

The Z6266 zircon (CL image, see Appendix 6) yielded U concentrations for 53 spots, ranging from 804 to $1,113 \mathrm{ppm}$ (mean = $947 \pm 100$ ), ${ }^{232} \mathrm{Th} /{ }^{238} \mathrm{U}$ ratios from 0.217 to 0.230 (mean $=0.222$ \pm 0.002 ) and total radiogenic ${ }^{206} \mathrm{~Pb}$ contents from 60 to $87 \mathrm{ppm}$ (mean $=74 \pm 7$ ). The analytical data is seen in Table 3. In the Concordia diagram (Figure 4A), the analytical points defined a U-Pb age of $561.9 \pm 1.0$ Ma with low MSWD of 0.14. This age is very close to that obtained by Stern and Amelin (2003). ${ }^{206} \mathrm{~Pb} /{ }^{238} \mathrm{U}$ (Figure $4 \mathrm{~B}$ ) and ${ }^{207} \mathrm{~Pb} / 206 \mathrm{~Pb}$ (Figure $4 \mathrm{C}$ ) weighted
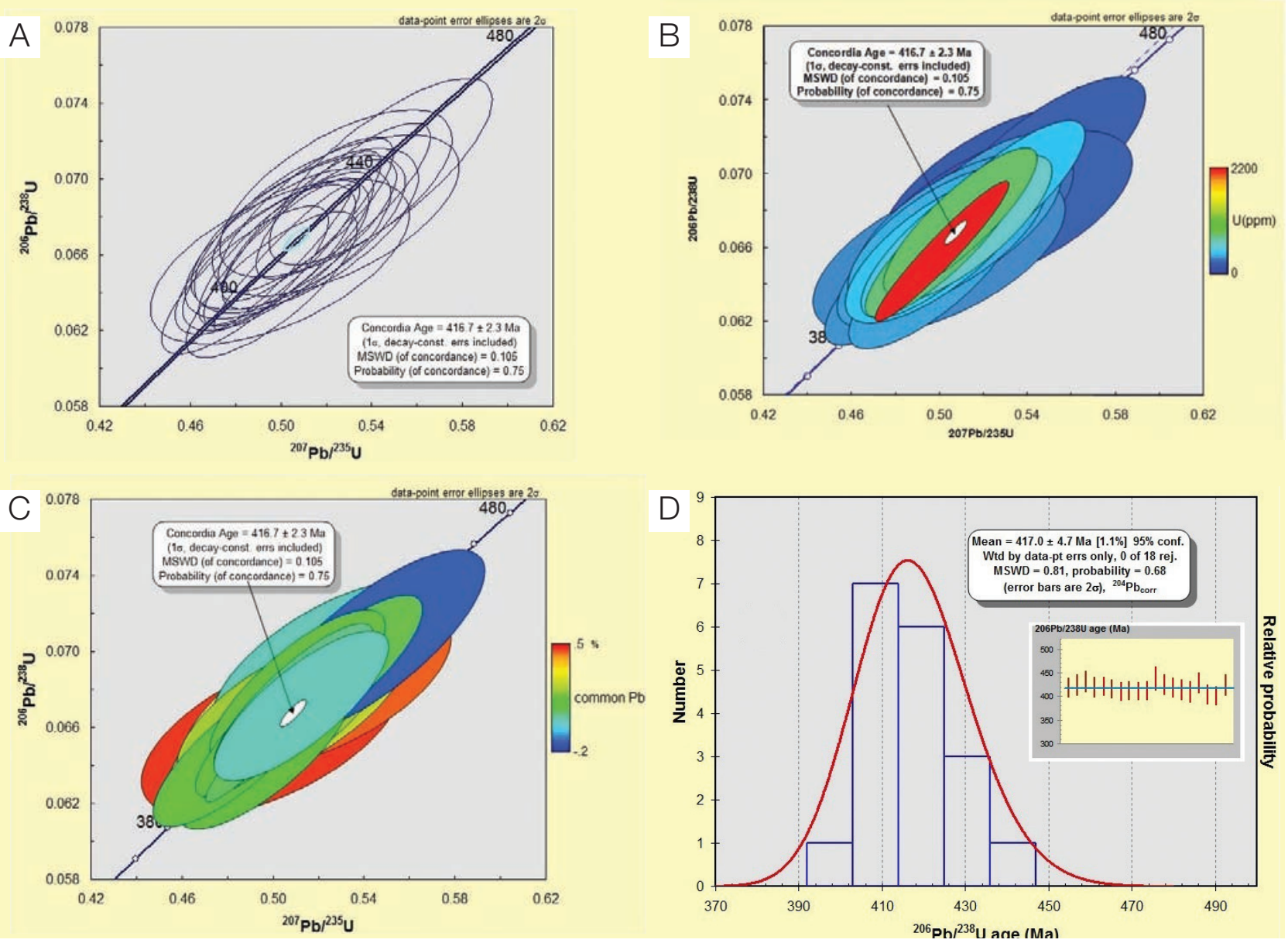

Figure 3. Temora analyzed as unknown sample. (A) Concordia diagram with age of $416.7 \pm 2.3 \mathrm{Ma}$; (B) Concordia diagram with $\mathrm{U}(\mathrm{ppm}$ - color scale) where the precision is directly proportional to the $\mathrm{U}$ concentration, but is dependent of common $\mathrm{Pb}$; (C) Concordia diagram with common $\mathrm{Pb}$ (error in \%, is directly proportional to the common $\mathrm{Pb}$ - color scale); (D) Histogram of ${ }^{206} \mathrm{~Pb} /{ }^{238} \mathrm{U}$ age (Ma) and analytical distribution (bar graph) of ${ }^{206} \mathrm{~Pb} /{ }^{238} \mathrm{U}$ age (Ma). (For data, see Table 3.) 

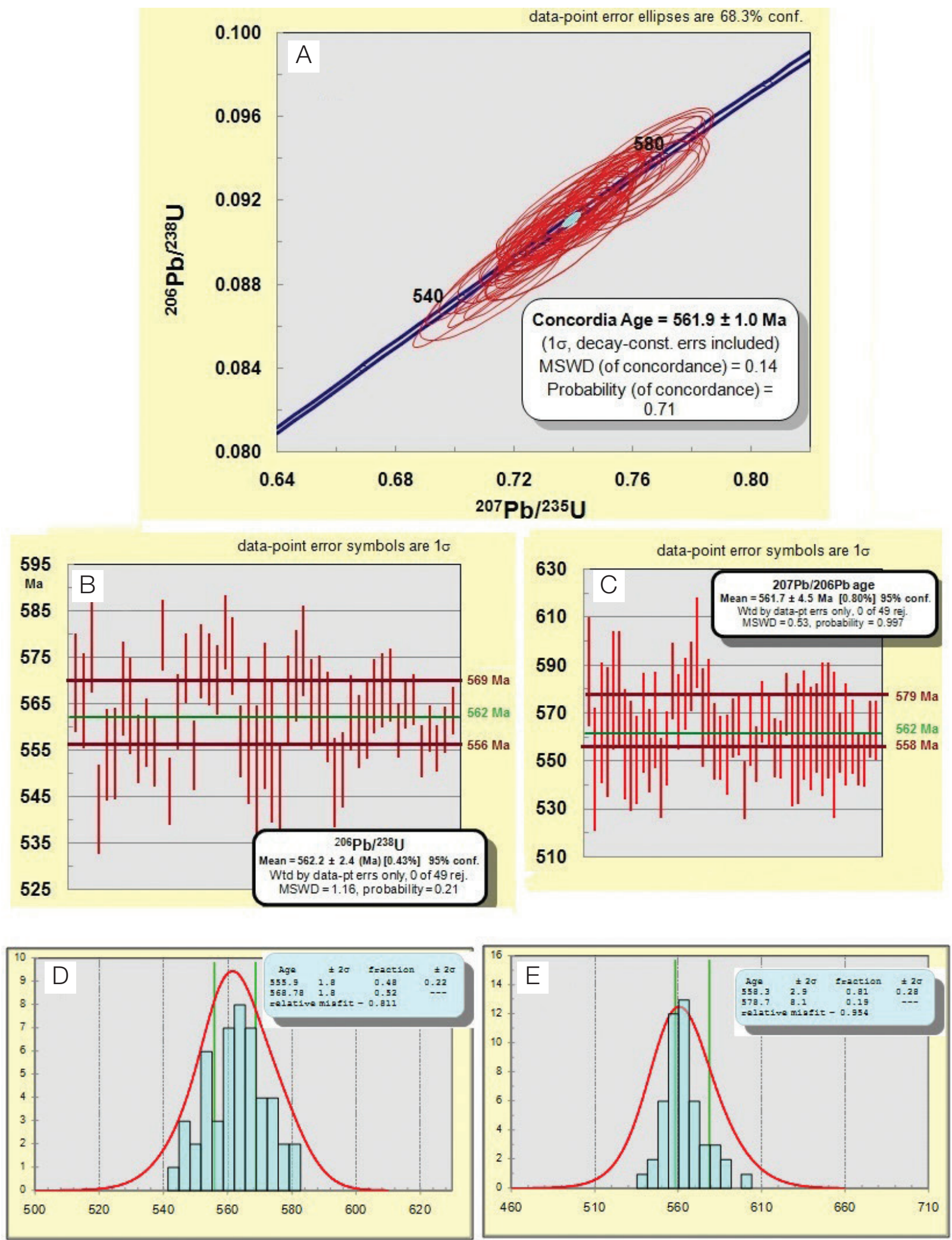

Figure 4. As shown in the Concordia diagram (A), Z6266 sample yielded a Concordia age of $561.9 \pm 1.0 \mathrm{Ma}$, which is in agreement with the ages presented by the Geological Survey of Canada (Amelin and Stern, 2003). (B) and (C) show a ${ }^{206} \mathrm{~Pb} /{ }^{238} \mathrm{U}$ and ${ }^{207} \mathrm{~Pb} /{ }^{206} \mathrm{~Pb}$ weighted average ages of $562.2 \pm 2.3 \mathrm{Ma}$ and $567.7 \pm 4.5$, respectively. The $\mathrm{PDP}$ of ${ }^{206} \mathrm{~Pb} /{ }^{238} \mathrm{U}$ and ${ }^{207} \mathrm{~Pb} /{ }^{206}$ ages shows a histogram illustrating a unimodal Gaussian distribution (D and E). (For data, see Table 3.) 
average ages are $562.2 \pm 2.4$ Ma and $561.7 \pm 4.5$ Ma respectively; therefore, these values are very close for Concordia age. The probability density plot (PDP, Figure 4D) of ${ }^{206} \mathrm{~Pb} /{ }^{238} \mathrm{U}$ and ${ }^{207} \mathrm{~Pb} /{ }^{206} \mathrm{~Pb}$ ages shows an unimodal Gaussian distribution. If we considered a possibility of 2 events, then the ages for ${ }^{206} \mathrm{~Pb} /{ }^{238} \mathrm{U}$ using unmixing of superimposed Gaussian distributions for 2 components, these ages are 556 and $569 \mathrm{Ma}$ (Figures 4B and 4D) and the ${ }^{207} \mathrm{~Pb} /{ }^{206} \mathrm{~Pb}$ ages for 2 components are 558 and $579 \mathrm{Ma}$ (Figures 4C and 4E). In the present moment, due to unimodal Gaussian distribution and uniform CL crystal images, we considered the Concordia value of $561 \mathrm{Ma}$ as the correct age. We consider the age variation observed in the Z6266 standard as a small heterogeneity. As we can observe, the same problem occurs in all other standards, which indicates that until today perfect natural zircon standard was not yet found.

\section{OG1 zircon sample}

Zircons from OG1 Archean sample (CL image, see Appendix 7) were analyzed by SHRIMP IIe and yielded a U-Pb age (Figure 5A) of $3462.6 \pm 5.1$, as shown in the Concordia diagram. The bar graph showed a weighted average ${ }^{207} \mathrm{~Pb} /{ }^{206} \mathrm{~Pb}$ age of $3462.6 \pm 5.1 \mathrm{Ma}$ (Figure 5B and Table 3), which is very close to $\mathrm{U}-\mathrm{Pb}$ zircon age of $3465.4 \pm 0.6 \mathrm{Ma}$ obtained by TIMS (Stern et al., 2009).

\section{EXAMPLES OF SHRIMP IIE U-Pb ZIRCON AGES FROM SOUTH AMERICAN SAMPLES ANALIZED AT GeoLab-IGc-USP}

To illustrate the precision of the ages obtained in terms of MSWD values and age errors, samples with different ages along the geological timeline were selected. Approximately hundreds samples were analyzed at GeoLab-IGc-USP using SHRIMP IIe. Out of these, seven samples are presented, as follows:

(a) Cenozoic zircon (Henrichs et al., 2012): the zircon sample was collected from Miocene subvolcanic intrusive rocks of the Yarumalito porphyry gold deposit, located at the Marmato Mining district, Colombia. The 16 YARSV zircon grains yielded a ${ }^{238} \mathrm{U} /{ }^{206} \mathrm{~Pb}$ weighted mean age of $7.0 \pm 0.15$ Ma with a MSWD of 1.08. Seventeen U-Pb zircon analyses from the YARNV sample yielded a ${ }^{238} \mathrm{U} /{ }^{206} \mathrm{~Pb}$ weighted mean age of $6.95 \pm 0.16 \mathrm{Ma}$, with a MSWD of 1.07;

(b) Cretaceous zircon (Basei et al., 2012): zircon samples from the Juína kimberlitic Province showed a single population with a ${ }^{206} \mathrm{~Pb} /{ }^{238} \mathrm{U}$ mean age of $92.1 \pm 2.4 \mathrm{Ma}$ and MSWD = 0.087;

(c) Cambrian zircon (Janasi et al., 2012): zircon samples from the Santos and Guarujá granite plutons, shown by regional geologic mapping to be post-orogenic, analyzed by SHRIMP IIe, yielded Concordia ages of $497.3 \pm 3.5 \mathrm{Ma}(\mathrm{MSWD}=0.035)$ and $496.9 \pm 4.3 \mathrm{Ma}$ (MSWD = 0.033), respectively;

(d) Neoproterozoic zircon (Araujo et al., 2012): zircon samples from the Tamboril-Santa Quitéria Complex, NE Brazil, analyzed by SHIRMP IIe, yielded Concordia ages ranging from $889 \pm 9.2 \mathrm{Ma}$ (orthogneiss, MSWD = 0.004) to $618 \pm 4.1$ (diatexite, MSWD = 0.37);

(e) Mesoproterozoic zircon (Payolla et al., 2012): the Alto Candeias Intrusive Suite has been interpreted as a product of inboard magmatism related to the Rondonian-San Ignacio orogeny. The analyses by SHRIMP IIe in the oscillatoryzoned cores yielded concordant ages of $1349 \pm 9.4 \mathrm{Ma}(\mathrm{n}=7$, MSWD = 1.9) and $1330 \pm 12 \mathrm{Ma}(\mathrm{n}=6$, MSWD = 2.4) for samples WB-731 and WB-305, respectively;
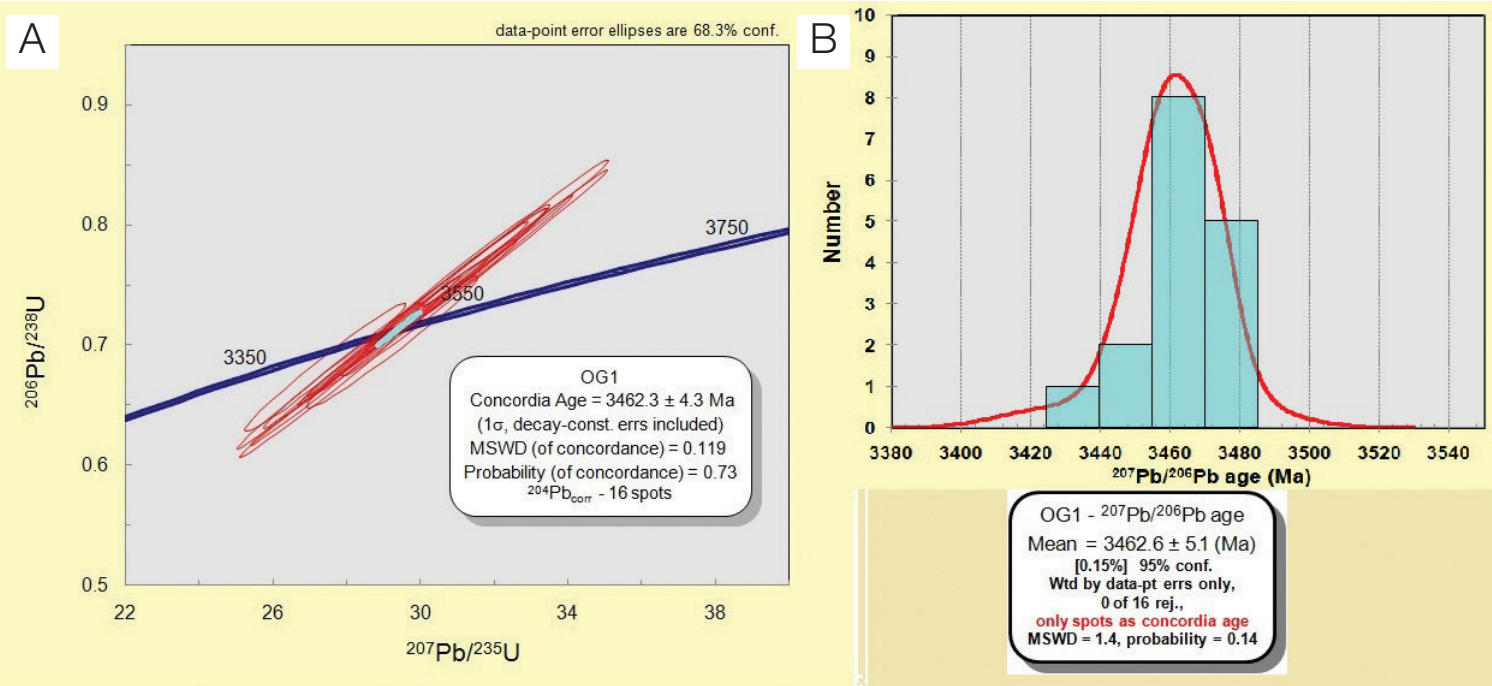

Figure 5. OG1 sample/standard - The Concordia diagram (A) shows a Concordia age of $3462.3 \pm 4.3$. The ${ }^{207} \mathrm{~Pb} /{ }^{206} \mathrm{~Pb}$ histogram (B) shows a weighted average age of 3462.6 $\pm 5.1 \mathrm{Ma}$, which is very close to the data by Stern et al. (2009). 
(f) Paleoproterozoic zircon (Sato et al., 2012): sample 2 BBV 40 was collected from the quartzite gneiss located near the Barra Velha region, Santa Catarina State. Among the detrital zircons, two different populations can be identified by their transparent and dark colors (CL images). Eighty five (85) out of one hundred and nine (109) spots are concordant and yielded a Concordia age of $2193 \pm$ $5.7 \mathrm{Ma}(\mathrm{MSWD}=0.0018) .{ }^{207} \mathrm{~Pb} /{ }^{206} \mathrm{~Pb}$ weighted average age is $2191.9 \pm 2.5 \mathrm{Ma}$ (mean of 102 spots, error = $0.11 \%$, MSWD $=1.1$, which is, therefore, very close to the Concordia age. These ages are very close to the Concordia age of $2182 \pm 9$ Ma dated by U-Pb TIMS method, and are not very different from Concordia age of $2199 \pm 16$ Ma dated by the LA-ICP-MS method;

(g) Archean zircon (Moreto et al., 2012): in the Carajás Domain, the iron, copper and gold oxide deposits from Sossego and Castanha are located in the South Belt, along a regional shear zone trending WNW-ESE, close to the contact between the Carajás basins and basement rocks. The Sossego gabbro-norite and the Castanha porphyry of rhyolitic and dacitic composition were dated by SHRIMP IIe and yielded zircon U-Pb ages of $2739 \pm 6 \mathrm{Ma}$ (MSWD $=1.4)$ and $2745 \pm 4 \mathrm{Ma}(\mathrm{MSWD}=0.18)$, respectively.

The examples above show ages from Cenozoic to Archean and do not include Figures and Tables, since the final papers are still being prepared. Dating of young zircons is critical for Cenozoic samples due to the low amount of radiogenic $\mathrm{Pb}$. Until now, the youngest ${ }^{206} \mathrm{~Pb} /{ }^{238} \mathrm{U}$ age of zircons is $7 \mathrm{Ma}$, with an error smaller than 0.2 Ma.

\section{U-Pb DATING FOR OTHERS MINERALS (TITANITE, XENOTIME AND MONAZITE) IN THE NEAR FUTURE}

Many tests were already done for dating other minerals, as titanite, xenotime and monazite.U-Pb dating for titanite mineral using Khan and BLR1 titanite standards was tested with success (Sato et al., 2014 in the $9^{\text {th }}$ South American Symposium on Isotope Geology). We also tested with success the dating $\mathrm{U}-\mathrm{Pb}$ in xenotime using MG standard and monazite using 44069 standard (from Pennsylvania). For near future (2015), we have project to buy cesium gum source to analyze oxygen isotopes in zircon (stable isotopes).

\section{CONCLUSION}

The Sensitive High Resolution Ion Microprobe is used at the laboratory of São Paulo University (GeoLab-IGc-USP) to measure $\mathrm{U}, \mathrm{Pb}$ and $\mathrm{Th}$ abundances, and isotopic relationships of these elements in zircon crystals. The spectrometer operates
24 hours per day, obtaining accurate data, which was approved to be published in internationally renowned magazines. The analytical quality of data obtained by SHRIMP IIe at the GeoLab-IGc-USP is of the same standard when compared to the data from leading laboratories, which was confirmed by an Inter-Laboratory Comparison (ILC) conducted in the $6^{\text {th }}$ International SHRIMP Workshop, 2012, Brisbane, Australia. Four samples with unknown ages (Archean, Paleoproterozoic, Paleozoic and Cenozoic) were distributed to 10 international laboratories, and ILC participants anonymously presented the results in this workshop, which were very similar and vary within the experimental error. The Temora 2 zircon standard (416.78 Ma, Black et al., 2004) analyzed for a continuous period of 72 hours by SHRIMP IIe at the IG-USP yielded an age of $416.8 \pm 3.8 \mathrm{Ma}$ with a corresponding error of $0.9 \%$. The OG1 Archean zircon samples (TIMS ages of 3465.4 $\pm 0.6 \mathrm{Ma}$, Stern et al., 2009) and the Z6266 Neoproterozoic zircon $\left({ }^{206} \mathrm{~Pb} /{ }^{238} \mathrm{U}\right.$ age of $559 \pm 0.2 \mathrm{Ma}-\mathrm{TIMS}$ analysis, Stern and Amelin, 2003) analyzed by SHRIMP IIe at the IG-USP yielded concordant ages of $3462.6 \pm 5.1$ Ma and $561.9 \pm$ 1.0 Ma, respectively, which are, therefore, very close to values found in the literature. Since concentrations of $\mathrm{U}$, Th and $\mathrm{Pb}$ are similar for $\mathrm{Z} 6266$ zircon, and ${ }^{207} \mathrm{~Pb} /{ }^{206} \mathrm{~Pb}$ and ${ }^{206} \mathrm{~Pb} /{ }^{238} \mathrm{U}$ ratios are relatively constant for OG1 zircon crystals, these crystals can be used as standard for SHRIMP analysis. The precision of the analytical data for $\mathrm{U}, \mathrm{Pb}$ and Th in zircons from samples collected in Brazil and neighboring countries is compatible with international standards.

\section{ACKNOWLEDGEMENTS}

We are grateful to Fundação de Amparo à Pesquisa do Estado de São Paulo (FAPESP), Petróleo Brasileiro S.A. (PETROBRAS), Agência Nacional do Petróleo, Gás Natural e Biocombustíveis (ANP), and Financiadora de Estudos e Projetos (FINEP) for financial support to install SHRIMP IIe. We are also grateful to Professor Umberto G. Cordani for starting this project, Dr. Koji Kawashita for providing us with the initial (1974) training in TIMS mass spectrometer, Professor Ian Williams for providing us with training (2007) in SHRIMP at the Australian National University, Canberra, Australia, and Australian Scientific Instruments staffs (John Hyder, Josif, Raad, Jorgen, David, Richard and Marc). We are grateful for the reviewers Dr. Hongyan Geng, University of Hong Kong, and the other anonymous, for their very constructive comments.

\section{REFERENCES}

Araujo, C. E. G de, Cordani, U. G, Basei, M. A. S., Sato, K. (2012). Arc reworking during collision: combined Lu-Hf LA-ICP-MS and U-Pb SHRIMP results from Tamboril - Santa 
Quitéria Complex, NE Brazil. $6^{\text {th }}$ International SHRIMP Workshop, extended abstract. Brisbane, Australia.

Basei, M. A. S., Svisero, D., Sato, K., Iwanuch, W., Tassinari, C. C. G., Sproesser W. M. (2012). U-Pb zircon ages and Hf isotopes from zircon megacryst: Alto Parnaíba (Minas Gerais) and Juína (Mato Grosso) kimberlitic provinces, Brazil. $6^{\text {th }}$ International SHRIMP Workshop, extended abstract. Brisbane, Australia.

Black, L. P., Kamo, S. L., Allen, C. M., Davis, D. W., Alenikoff, J. N., Valley, J. W., Mundif, R., Campbell, I. H., Korsch, R. J., Williams, I. S., Foudoulis C. (2004). Improved $206 \mathrm{~Pb} 238 \mathrm{U}$ microprobe geochronology by the monitoring of trace element related matrix effect; SHRIMP, ID-TIMS, ELA-ICP-MS and oxygen isotope documentation for a series of zircon standards. Chemical Geology, 205(1), 115-140.

Clement, S. W., Compston, W., Newstead, G. (1977). Design of a large, high resolution ion microprobe. In: Proceedings of the International Conference on SIMS and Ion Microprobes, Muenster, Germany (unpublished ms.).

Compston, W. (2000). Interpretation of SHRIMP and isotope dilution zircon ages for the geological time-scale: I. The early Ordovician and late Cambrian. Mineralogical Magazine, 64(1), 43-57.

Compston, W., Williams, I. S., Meyer, C. (1984). U-Pb geochronology of zircon from lunar breccia 73217 using a sensitive high mass resolution ion microprobe. Journal of Geophysical Resources, 89, Supplement, B525-B534.

Henrichs, I. A., Frantz, J. C., Marques, J. C., Sato, K. (2012). Characterization and Age of the Yarumalito Gold Porphyry, Colombia. VIII South American Symposium on Isotope Geology, abstract. Medellin, Colombia.

Ireland, T. R., Clement, S., Compston, W. (2008). Development of SHRIMP Australian, Journal of Earth Sciences, 55(6), 937-954.

Janasi, V.A., Siga Jr., O., Sato, K., Machado, F. B., Soares Jr., A. V., Magalhães, A. O. B. F., Machado,A. V.(2012). The young guys are in town: a $\sim 500 \mathrm{Ma} \mathrm{U}-\mathrm{Pb}$ Shrimp age for the Santos and Guarujá granites extends further south the Ribeira “G5” magmatism. $46^{\circ}$ Congresso Brasileiro de Geologia. Santos, São Paulo.

Ludwig, K. (2009). SQUID 2: A User's Manual, rev. 12 Apr, 2009. Berkeley Geochronology Center, Special Publication 5, 110 p.

Matsuda, H. (1974). Double focusing mass spectrometers of second order. International Journal Mass Spectrometry and Ion Physics, 14(2), 219-233.
Moreto, C. P. N., Monteiro, L. V. S., Xavier, R. P., Sato, K., Amaral, W. S., Kemp, T. (2012). Geocronologia U-Pb SHRIMP IIe e LA-ICPMS em zircão das rochas hospedeiras dos depósitos IOGC do cinturão sul do cobre, Carajás: Implicações metalogenéticas e para a evolução crustal. $46^{\circ}$ Congresso Brasileiro de Geologia. Santos, São Paulo.

Payolla, B. L., Bettencourt, J. S., Leite Jr., W. B., Sato, K. (2012). U-PbSHRIMPzircon ages of charnokites of Alto Candeias intrusive suit, Rondônia, Brazil: Implications for the magmatism related to the Rondonian-San Ignacio Orogeny. VIII South American Symposium on Isotope Geology, abstract. Medellin, Colombia.

Sato, K., Basei, M. A. S., Tassinari, C. C. G., Siga Jr., O. (2012). U-Pb SHRIMP IIe Dating of Detrital Zircon from Santa Catarina Quartzite - Luiz Alves Craton, South American Platform. $6^{\text {th }}$ International SHRIMP Workshop, extended abstract. Brisbane, Australia.

Sato, K., Basei, M. A. S., Tassinari, C. C. G., Siga Jr., O., Onoe, A. T. (2014). The application of U-Pb geochronology to titanite by SHRIMP. $9^{\text {th }}$ South American Symposium on Isotope Geology. São Paulo, SP.

Sircombe, K., Stern, R. A. (2002). An investigation of artificial biasing in detrital zircon U-Pb geochronology due to magnetic separation in sample preparation. Geochimica et Cosmochimica Acta, 66(13), 2379-2397

Stacey, J. S., Kramers, J. D. (1975). Approximation of terrestrial lead isotope evolution by a two-stage model. Earth and Planetary Science Letters, 26(2), 207-221.

Stern, R. A. (2001). A new isotopic and trace element standard for the ion microprobe: preliminary TIMS U-Pb and electron microprobe data, current research. Radiogenic age and isotopic studies: Report 14. Geological Survey of Canada. Ottwa, Canada.

Stern, R. A., Amelin, Y. (2003). Assessment of errors in SIMS zircon U-Pb geochronology using a natural zircon standard and NIST SRM 610 glass. Chemical Geology, 197(1), 111-142.

Stern, R. S., Bodorkos, S., Kamo, S.L., Hickman, A. H., Corfu, F. (2009). Measurement of SIMS Instrumental mass fractionation of $\mathrm{Pb}$ isotopes during zircon dating. Geostandard and Geonalytical Research, 33(3), 145-168

Williams, I. S. (1998). U-Th-Pb geochronology by ion microprobe. In: M. A. McKibben, I. Shanks, W. C. P. Ridley, W. I. Ridley (Eds.), Application of Microanalytical Techiniques to Understanding Mineralizing Process (1-35). Reviews in Economic Geology. Socorro, USA: Society Geologists. 


\section{APPENDIX 1}

\section{Sample preparation and hand picking}

Zircon grains were extracted by standard crushing, milling, sieving $(0.150-0.063 \mathrm{~mm})$, Wiffley table, and heavy liquid techniques (bromoform - density $=2.85$ and metilene - density $=3.32$ ). Five to seven fractions (magnetic to nonmagnetic) were separated using the Frantz magnetic barrier separator and after removing ferromagnetic minerals by a hand magnet. Normally, the ideal fraction for igneous zircon is non magnetic.

For detrital zircon (Sircombe and Stern, 2002), taking the nonmagnetic fraction at a Frantz setting of 1.8 A $10^{\circ}$ side-slope, or a mass magnetic susceptibility of $4.72 \times 10^{-7}$ e.m.u./g $\left(5.93 \times 10^{-9} \mathrm{~m}^{3} / \mathrm{kg}\right)$ is a reasonable compromise between representation and analytical efficiency. The handpicking process in detrital zircon geochronology attempts to ensure the most-representative sampling possible within the limitations imposed by handling small-sized samples. No preferential selection of zircon was made based on size, color, shape, roundness and metamictization. This aim is best achieved by minimizing individual grain handling and hand picking only to ensure purity of zircon content as a group rather than the quality of individual grains. Extracted zircon grains were poured into a mound under alcohol in a Petri dish. This mound was directly mixed and then a swathe swept from the middle. Non-zircon grains were removed from this swathe, and the remaining zircon grains, typically numbering 100 to 150 grains, were taken from the dish using a pipette. Zircon grains were mounted on doublesided adhesive tape before being set in an epoxy disk and polished to reveal half-sections. Zircon internal structures were analyzed.

Appendix 2. Secondary beam mass scan: [top (left)] ${ }^{254}(\mathrm{UO})$ mass scan with resolution of 5065 at $1 \%$; [top (right)] ${ }^{206} \mathrm{~Pb}$ mass scan with resolution of 5016 at 1\%; [bottom (left)] ${ }^{207} \mathrm{~Pb}$ mass scan with resolution of 5200 at $1 \%$; [bottom (right)] ${ }^{238} \mathrm{U}$ mass scan with resolution of 5300 at $1 \%$.
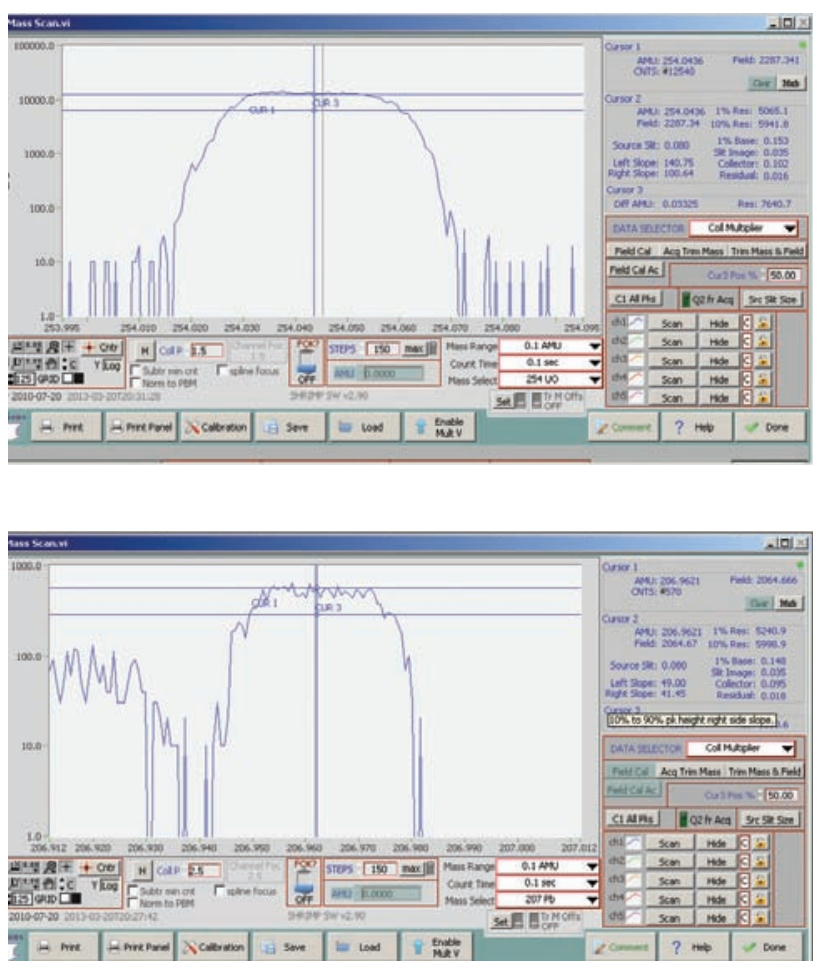
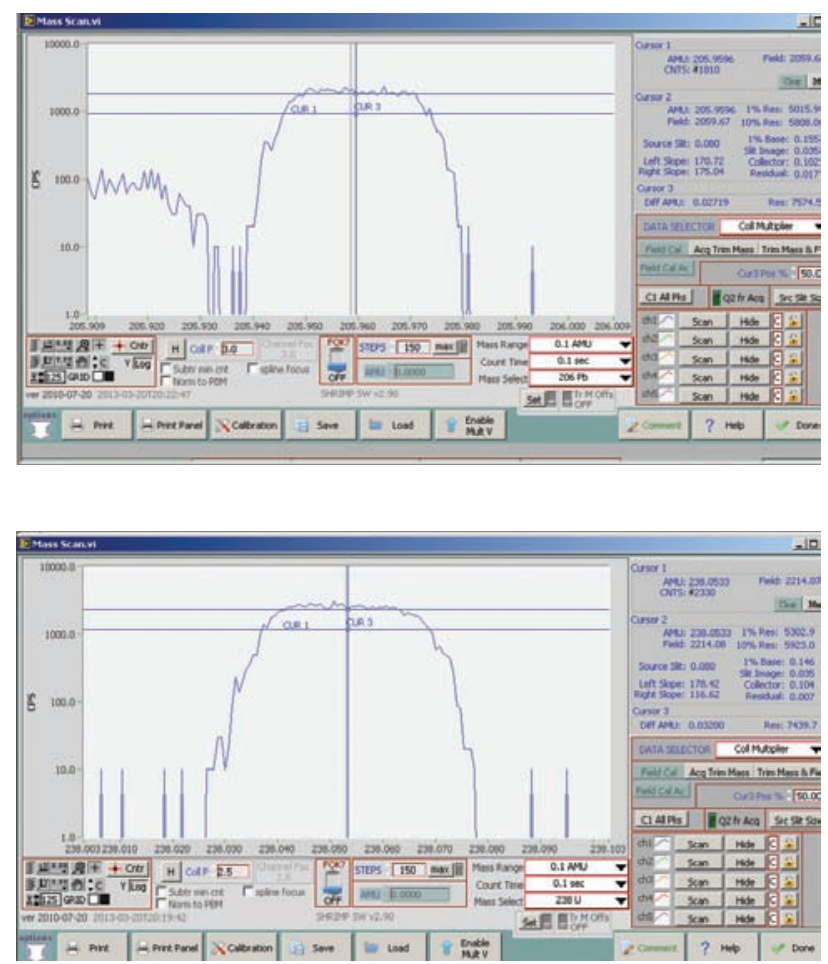
Appendix 3. Primary beam calibration: [top (left)] mass scan of oxygen negative ions $\mathrm{O}^{-}(10 \otimes A)$ and $\mathrm{O}_{2}^{-}(5 \otimes A)$; [top (right)] Source Steering Z deflection; [bottom (left)] Source Steering Y deflection; [bottom (right)] Wien electrostatic steering Z deflection. Scan done at 2013 April.
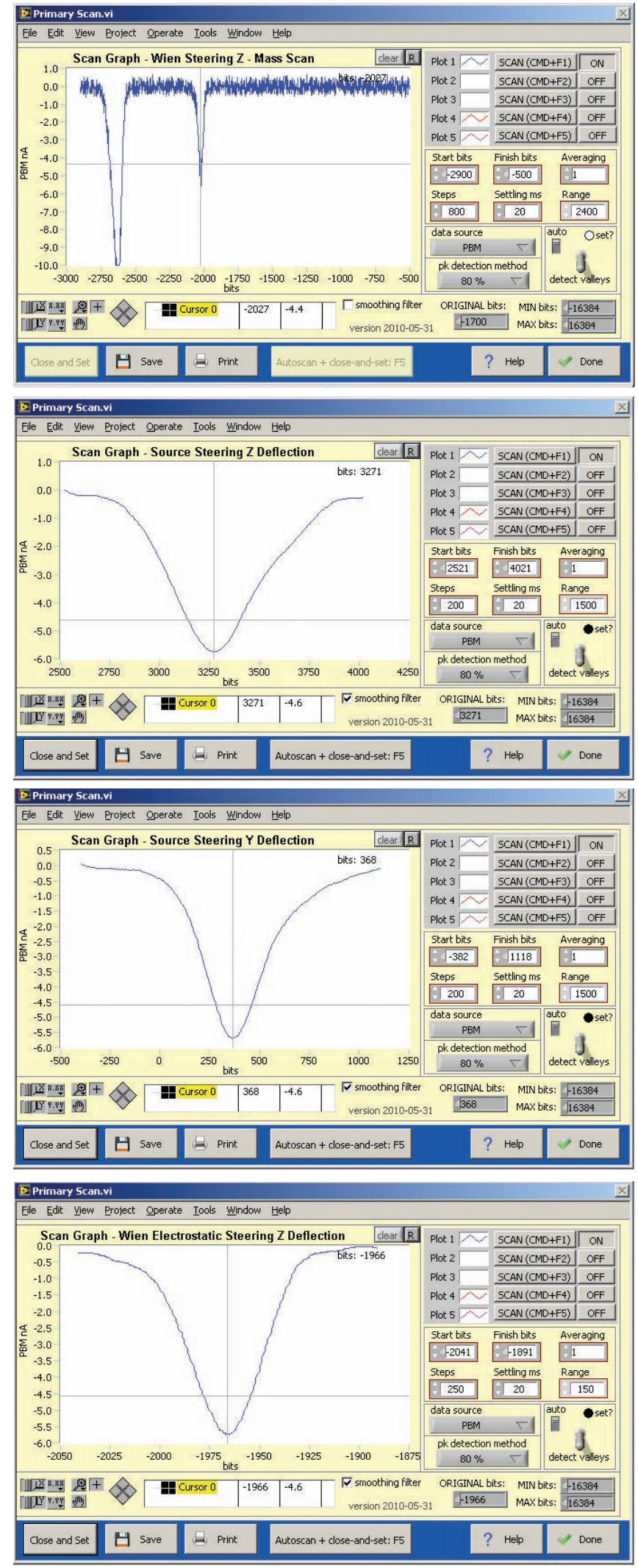
Appendix 4. Secondary beam - focus alibration: (A) quadrupole triplet $1 \mathrm{Y}$ deflection; (B) quadrupole $1 \mathrm{Z}$ deflection.
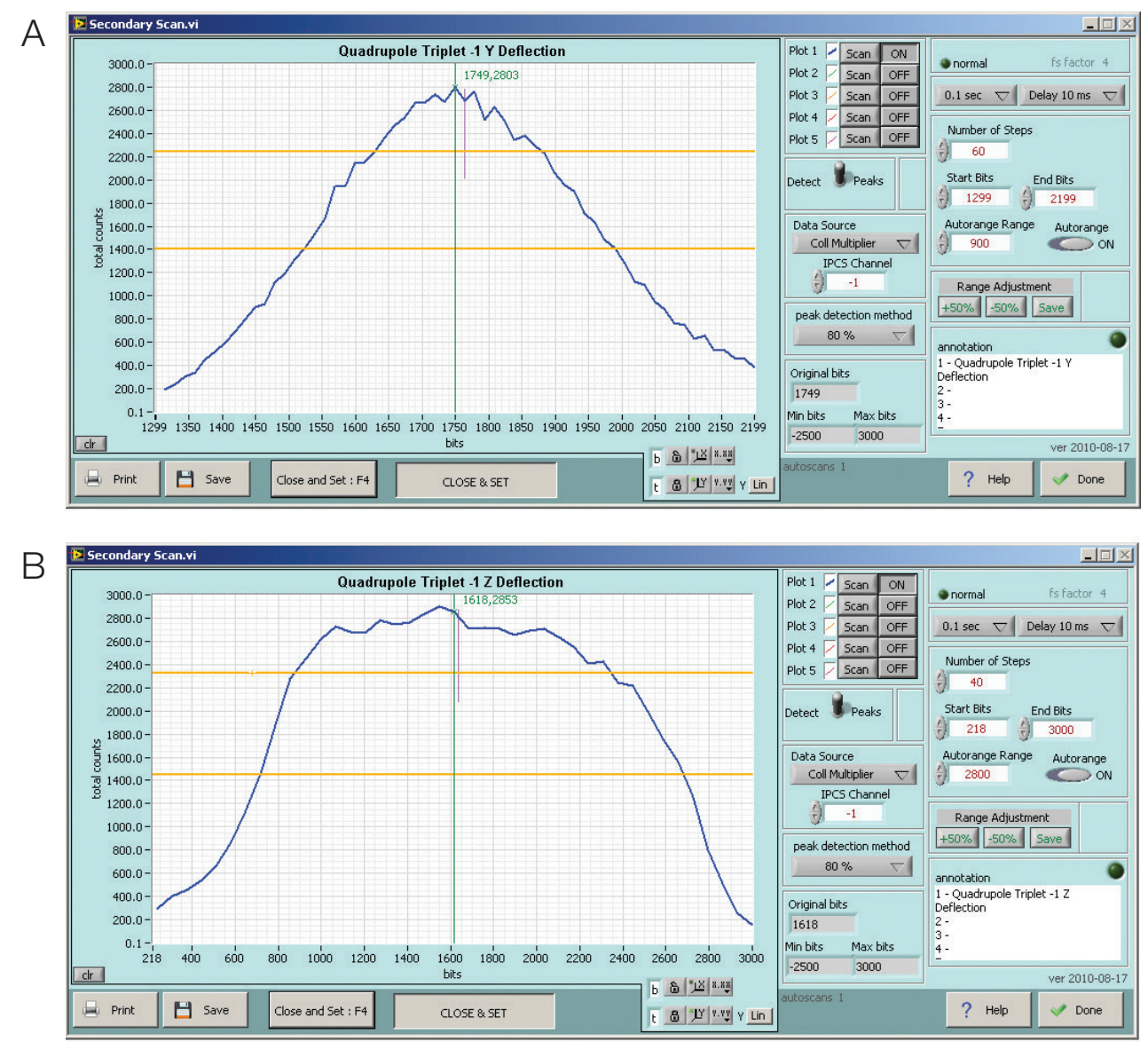

Appendix 5. Temora 2. (A) Cathodeluminescence image (CL); (B) secondary electron image (SE). The numbers at CL are spot points.

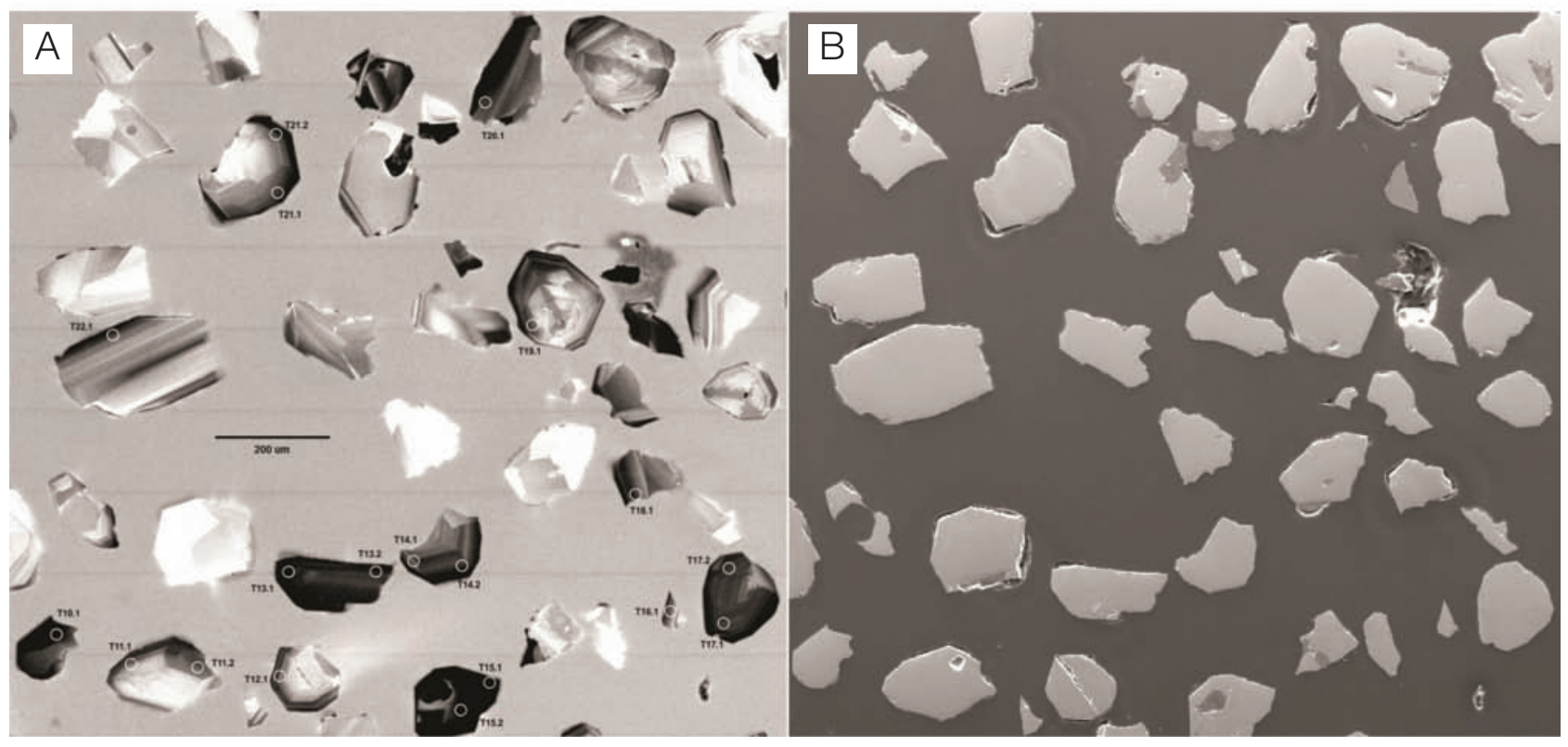


Appendix 6. Cathodeluminescence (CL) image of Z6266 zircon glassy fragments obtained from a single Sri Lankan megacryst, Australia. In fragmented form, it appears clear and colorless with no observable internal heterogeneities, and in the CL no detectable variations were observed.
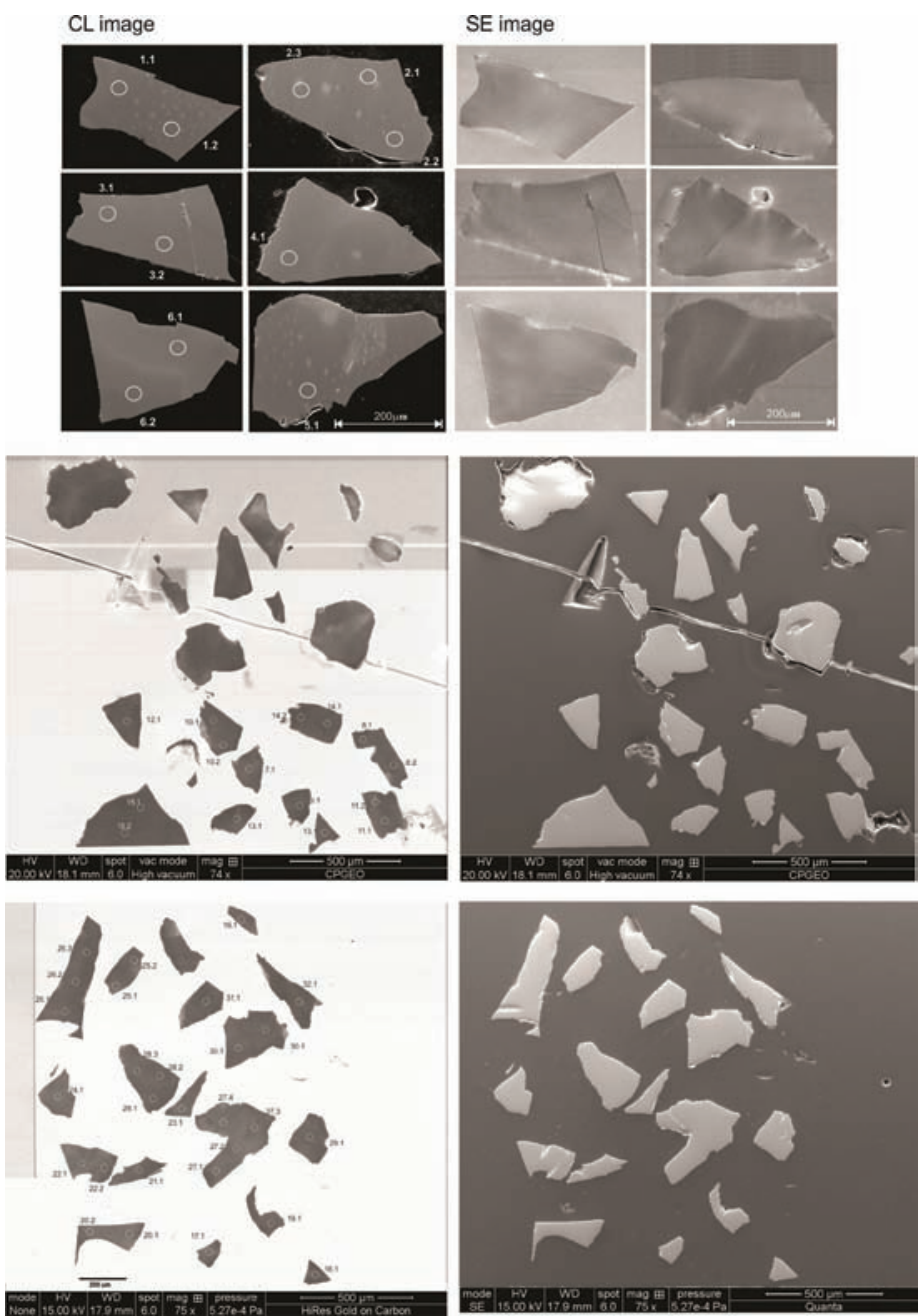

Appendix 7. Cathodeluminescence (CL) image from OG1 zircon crystal from Owens Gully diorite of Pilbara Craton, Western Australia. These crystals are from SHIMP Ile setup mount. They were generally $100-300 \mu \mathrm{m}$ in largest dimension, stubby prismatic, to sub equant grains dominated by pyramidal faces. CL images typically revealed simple branding parallel to crystallographic c-axis, or sector zoning in equant grains (Stern et al., 2009).

\section{CL image}

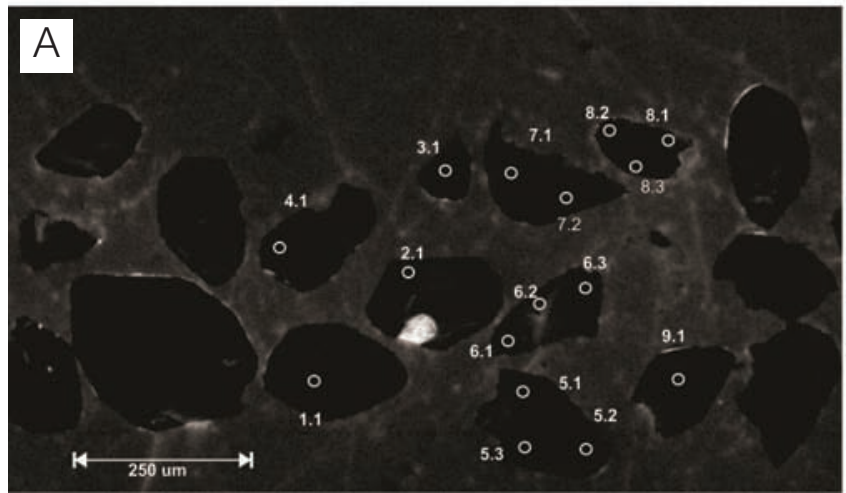

\section{SE image}

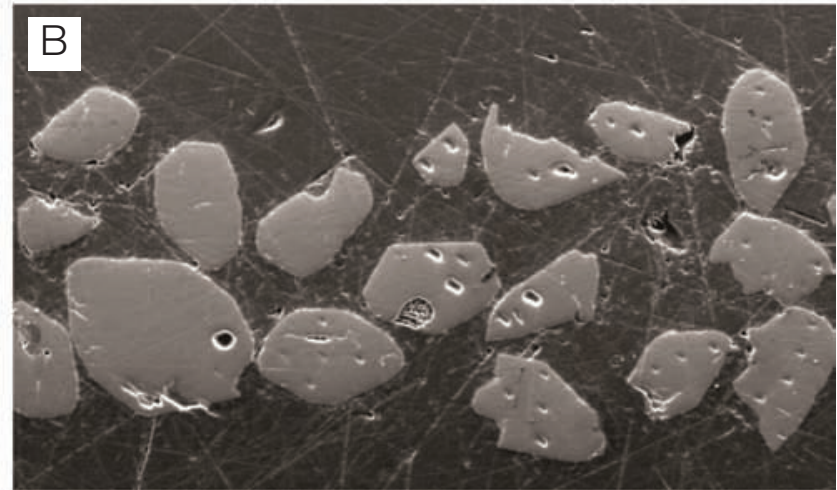

